Peter Bofinger, an economist at the Landeszentralbank in Baden-Württemberg, Germany, was a visiting scholar at the Federal Reserve Bank of St. Louis. Scott Leitz provided research assistance.

\title{
The German Monetary Unification (Gmu): Converting Marks to D-Marksi
}

UE MONETARY and economic unification of the East and West German economy is a task without precedent in peacetime economic history. It not only merges two countries with strongly divergent income and productivity levels, but also unifies two economies with radically different economic structures-the German Democratic Republic's (GDR) centrally planned economy and the Federal Republic of Germany's (FRG) "social market economy." Although conventional wisdom calls for gradualism in the process of monetary and economic unification of capitalist economies and in the transition process from socialism to a market economy, in the German case, these tasks will be accomplished virtually overnight. $^{2}$

The legal basis for the unification process is the treaty ratified by the East and West German parliaments on June 21, 1990, which took effect on July 1, 1990. The agreement outlines the principles for monetary union, the economic and social community of the two states and the fiscal reform of East Germany.

The arrangements for monetary union, which involved the replacement of the East German "Mark" (M) by the West German "Deutsche Mark" (DM), established the rates at which East German financial stocks and flows would be converted from their Mark values to D-Mark values. A 1M:1DM rate was applied to East German wages, salaries, rents, leases and pensions. Savings accounts of GDR citizens were converted at a 1M:1DM rate up to a limit of $M$ 4,000 (approximately $\$ 2,425$ at the current DM $/ \$$ exchange ratel for persons between 15 and 59 years of age. The corresponding limit
At the present time, discussion and anatysis of the Gmu has appeared primarily in German newspapers. I do not quote these articles explicitly in the paper. Publications of the Deutsche Insittut fuer Wirtschatsforschung, Berin, of Norbert Koten, Karl Oto Poehl, Helmut Schlesinger and Horst Siebert provided valuable insights and analysis. I have proflied from many discussions with Norbert Kloten and members of the Pesearch Deparment of the Federal Reserve Bank of St. Louis and of the Volkswirschatliche Abteilung der Landeszentrabank in Baden Wuertemberg.
2For the standard arguments, see Committee for the Study of Economic and Monetary Union (1989), ("Delors Committee:" $)$. In the debate on economic transformasion of socialist countries see, for instance, Daviddi and Espa (1989). There seems to be, however, a growing awareness that partial reforms generate only limited success: see Roe and Poy (1989). 
was M 6,000 for older persons and M 2,000 for younger persons. A 2M:1DM rate was used to convert all other financial assets and liabilities of GDR residents. Mark assets held by individuals who live outside the GDR were converted at a 3M:1DM rate.

The legal framework for the economic community between the two states and for the transformation of East Germany's economic order involves nearly a complete adoption of the FRG's economic laws and regulations by East Germany. These changes include the restoration of private property and competition in East Germany and the free movement of goods, services, labor and capital between East and West Germany. In addition, social welfare, pensions, unemployment and health insurance programs similar to those in West Germany were introduced into East Germany; any deficits in these new programs will be financed temporarily by the FRG. Pensions in East Germany were converted to DM values based on net East German incomes; an East German worker can receive a maximum pension of 70 percent of his or her net income after 45 years of employment. The agreement also guarantees that the DM value of East German pensions cannot fall below their former Mark equivalents.

Under the agreement, the East German government will abolish its old system of high tax levies on state enterprises and introduce, instead, a system of income and value added taxes consistent with those of West Germany. Future debt issues by the GDR government must be issued directly via the Deutsche Bundesbank or with its approval. The FRG will finance two thirds of the East German deficits from 1990 through 1994. For this purpose, a "German Unity" fund of DM 115 billion was launched; it will be financed by a combination of bond issues (DM 95 billion) and expenditure reductions in the FRG central government budget (DM 20 billion).

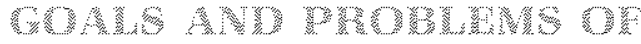

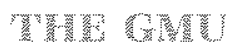

The paper starts with a short analysis of the economic situation in East Germany after the fall of the Wall. It tries to identify both the goals of the East German people and those of the West German government which together have led to the present unification of both $\mathrm{Ger}$ manys. A brief outline of the reforms necessary to transform the East German economy are discussed first. The rest of the paper focuses on monetary unification, certainly the most controversial issue in the debate over unification.

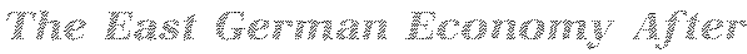

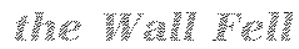

The deep economic malaise of the East German economy provides a good example of the general failure of the centrally planned economic systems of Eastern Europe. ${ }^{3}$ Prior to World War II, the part of Germany that now makes up the GDR was essentially as developed as those regions which now constitute the $\mathrm{FRG}$. Data for 1936, for example, show that per capita income was 993 Reichsmark in the East and 996 Reichsmark in the West.

Today, of course, it is not as easy to assess the relative per capita incomes of the two Germanys. The GDR's administratively-set domestic prices and exchange rates do not accurately reflect its economic conditions; consequently, "official" data, when available, must be treated with skepticism. For example, the East German Statistical Office recently published the first official income estimate for East Germany; it reported that GDP was M 353 billion for 1989.4 Most West German estimates of the GDR's 1989 GNP range from $M 280$ billion to $M 300$ billion. $^{5}$ If a 1M 1DM conversion rate is used with these estimates, the GDR's 1989 per capita income was somewhere between DM 15,000 and DM $21,000,{ }^{6}$ only about half of that estimated for

3 See the detalled report of the instiute for International

Finance (1990).

4 Data for the GNP are not available.

5The lower flgure is an estimate of the Kiel Institute for Wotl wonomics; the higher flgure was estimated by the tive leading economic research institutes of the Foderal Pepublic in their repor of April 12, 1980.

- At the wresent QWWollar exchange rate of about $1.65 \mathrm{DH}$ per Dollar, this equals $\$ 9,000$ to $\$ 13,000$. For comparison, 1989 per capita income in the United States was $\$ 21,000$. 


\section{Table 1}

\section{Basic Data for East and West Germany (1988)}

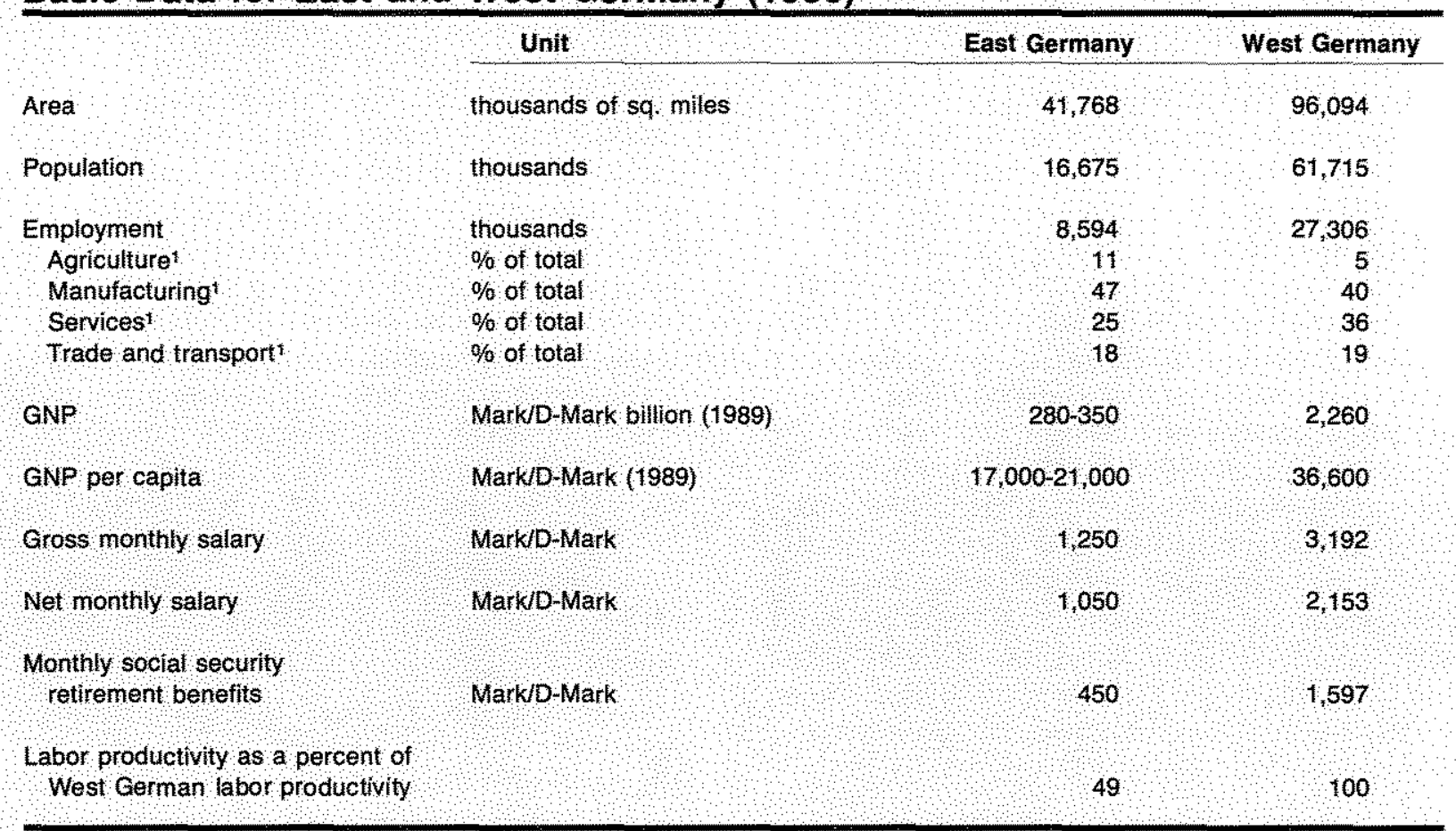

Data are for 1987.

SOURCES Otficial statistics of the GDR compiled by the Deutsche Bundesbank and Deutsches tnstitut fuer Wirtsehaftsforschung

the FRG (DM 36,600) in 1989 (table 1). Thus, despite East Germany's good educational system, its per capita income and, by proxy, its labor productivity, is estimated to be, at best, only half that of West Germany. ${ }^{7}$ Of course, these comparative productivity figures are likely to prove misleading if used to predict what might occur after unification takes place; for example, GDR products previously produced and sold under a central plan designed to achieve autarky may not be able to compete effectively with goods that can now be imported from the West.

The economic disparity between the FRG and the GDR is further demonstrated by the ex. tremely high environmental pollution in East Germany, its obsolete infrastructure, outdated manufacturing plants and the generally poor quality of its housing stock. Another indication of the disparity between the two Germanys is shown by the relatively high proportion of total employment devoted to agficulture and manufacturing in the GDR ( 58 percent) compared to that in the FRG (45 percent); indeed, the GOR's current proportion of employment in agriculture and manufacturing is roughly identical to that which prevailed in the Federal Republic over 20 years ago. ${ }^{8}$

In the past, the large difference in living stan dards between the two German states could be maintained only by the GDR's actions to close its borders with the West and prohibit virtually all unauthorized movement of labor, capital, goods and services between East and West Germany. Since the border became permeable in autumn 1989, more than 2000 East German citizens have moved into West Germany daily;
The 50 percent estmate for the GDR's relative labor procuctivity was made by the Deutsches institut fuer Wirtr schattsforschung, Berlin, in 1987 for the year 1983. It is nearly identical to Collier's (1985) estimate of 54 percent and to cross-country comparisons (see Cornelsen and
Kirner (1990)). However, the Kel institute for World Economics estimates that GDA labor productivity is only about 35 percent of West German levels.

see Gerstenberger (1990). 
as a result, between then and the first several months of 1990, the GDR's population decreased by about 500,000 persons.

This massive exodus was possible only because the West German constitution grants citizenship status to all East Germans. Among other things, this allowed East Germans who moved to West Germany to obtain immediate social benefits (unemployment benefits, retirement insurance and aid to the disadvantaged) that are tied to West German income levels. FRG unemployment payments, for example, are about 68 percent of West German net incomes; in comparison, net incomes in the GDR are only about one-third of that in the FRG. ${ }^{9}$ The substantial difference between West German unemployment benefits and East German income levels explains, in part, the massive migration of East German workers. However, these specific incentives were eliminated on July 1 , 1990, when the social community between both states was established. From that date, all social benefit payments to East Germans will be based on East German income levels, not on those in West Germany.

The migration of many skilled workers to the FRG caused the economic situation in the GDR to substantially deteriorate. Since November 1989, GDR industrial production and employ. ment has decreased and most East German enterprises have been unable to fulfill their production plans. By the end of April 1990, industrial production was 4.5 percent below its level one year before, and the number of employed persons had fallen by 4.6 percent. Shortages of goods and services produced growing social unrest in East Germany.

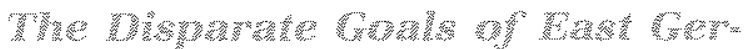

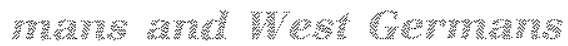

Given the circumstances described above, the goals of the GDR population are quite evident: They want to improve their relatively low standard of living as quickly as possible. Given the disappointing economic results associated with socialism, they were generally unwilling to experiment with a system part-way between socialism and capitalism. They chose, instead, immediate and complete integration with the Federal Republic of Germany even though they knew that it would require total restructuring of the East German economic and political systems.

The extreme political uncertainty in the GDR after the Wall fell, the obvious desire of the East German population to unify both countries and the massive outflow of East Germans into West Germany, which aggravated housing problems in the FRG, left little room for political maneuvering in West Germany and little time to find a solution that would satisfy both East and West Germans. Legally, of course, West Germany could not oppose rapid unification; the West German constitution (Article 23 of the "Basic Law") explicitly permits the East German states to join the Federal Republic without requiring the consent of either the West German Government or its Parliament. This excluded a variety of possible partial solutions and gradual approaches. ${ }^{\text {to }}$

Therefore, the main task facing West Germany was to design a unification strategy that would restore the confidence of East Germans in the future prospects of East Germany and, at the same time, be compatible with the chief interests of West Germans. Consequently, the debate in West Germany focused on the possible costs of the unification process. Among the costs mentioned were:

1. The possible increase in the West German inflation rate,

2. The prospects of either higher taxes or higher interest rates (due to increased FRG borrowing) resulting from increased FRG expenditures for East Germany, and

3. The wealth transfer from West Germans to East Germans associated with the replacement of Mark-denominated savings and cur. rency in the GDR by DM-denominated monetary assets.

Once the actual conversion rates are chosen, it is possible, albeit tentatively, to assess the impact of monetary unification on matters that concern the East and West Germans. The ten-
sPensioners moving to West Germany received an average pension of DR 1,121 (1988), more than twice the average East German pension in Marks.

10In fact, almost all West German economists as well as the Bundesbank preferred a more gradual approach involving either flexible or fixed exchange rates between the two currencies as an intermediate stage during the period of economic transformation in the GDR. 
tative nature of the assessment is chiefly due to the absence of reliable data on the East German economy and to the simultaneity of the monetary and political integration with the transformation of the East German economy. The short-term focus of the analysis should not lead to the impression that the risks and problems associated with unification of the two Germanys are either substantial or pervasive. The strong overall consensus in both German states is that the long-term prospects of unification are positive and that East Germany has the potential to repeat the "economic miracle" achieved by West Germany from the 1950 s to the present. ${ }^{11}$

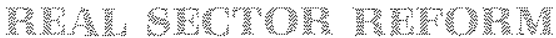

Although this paper focuses primarily on monetary unification, a brief discussion of the economic reforms necessary in the real sector of the GDR economy is needed. The Gmu itself will not improve the economic situation in East Germany substantially; it can provide, however, a sound monetary framework for an overall restructuring of the GDR's economic and legal system.

A cornerstone of real sector reform in the GDR will be the introduction of free-market pricing and production. Previously, most production and prices had been set by government agencies in accordance with their central plans. One consequence of this system-as in many other socialist countries-was that these prices had been held essentially unchanged for years despite changes in demand and cost conditions. ${ }^{12}$ For example, the GDR's official index for consumer prices has shown virtually no movement over the entire post-World War II era.

Moving to a market-based economy will require a number of changes. First, the current pricing structure is distorted by large subsidies for some industries, especially food and energy (their subsidies totaled M 50 billion in 1988, about one-third of total private expenditures in the GDR) and heavy taxes on other industries, primarily consumer durable goods (the tax totaled $\mathrm{M} 43$ billion in 1988). These distorting influences on prices will have to be reduced.
Second, the central planning approach to pricing and production must be replaced by the usual market mechanisms that determine these decisions in free-market economies. Not only must prices be set by market conditions rather than by government bureaucrats, but also the extensive system of state-owned enterprises must be privatized as well. In order for market prices and wages to successfully provide the signals for reallocating resources, the traditional "soft budget constraint" of state-owned enterprises has to be replaced by the "hard budget constraint" of profits, losses and, if necessary, strict bankruptcy laws. ${ }^{13}$

Third, the "Kombinate," which are conglomerates of GDR firms that produce similar products, have created an extremely high degree of horizontal concentration in the GDR economy; this has contributed to the GDR price inflexibility discussed previously. Consequently, price reform requires that these "Kombinate" be dismantled as soon as possible. However, even if this is not immediately forthcoming, the in troduction of the freely convertible D-Mark will create a more competitive environment because it will significantly open up the GDR's economic relations with West Germany and the rest of the world.

Thus, while there are many open questions concerning specifie details of how the divergent legal systems will be reconciled and how privatization will be achieved, there is wide acceptance that these are the central elements of real sector reform and that they will take place. ${ }^{14}$

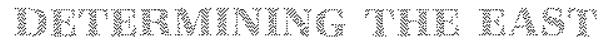

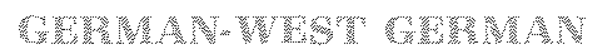

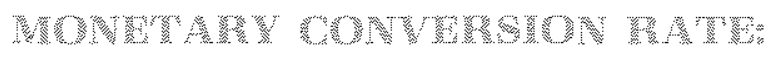

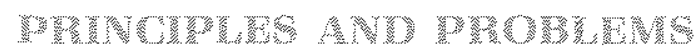

As noted previously, the major controversy over unification focused on monetary unification - that is, how to determine the rates at which GDR financial stocks and flows denominated in Marks would be converted into their appropriate D-Mark values. The main reason for the intensive debate was that none

\footnotetext{
1 See Institut der detischen Wirtschaft (1990).

${ }^{12}$ See the survey conducted by Commander and Coricelli (1990).
} 
of the existing exchange rates between the Mark and the D-Mark seemed relevant for determining the D-Mark value of GDR financial stocks and flows after unification. In this respect, the Gmu is quite different from the formation of a monetary union between two or more market economies. For instance, the appropriate conversion rate was easily determined when Saarland, which had become independent from Germany after the World War II, was unified with the FRG in 1959. In this instance, Saarland's financial flows and stocks, which had been denominated in French Francs prior to unification, were simply converted to their DM values at the prevaling market exchange rate between the Franc and the D-Mark.

In the case of Gmu, however, all existing exchange rates were either highly distorted or essentially devoid of economic significance. The same criticism applies to the macroeconomic data that might otherwise have been used to calculate an "equilibrium exchange rate" on the basis of the traditional exchange rate models. ${ }^{15}$

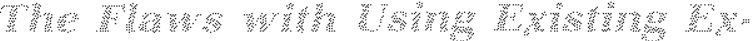

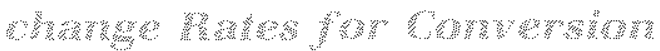

After the fall of the Wall, the one market exchange rate between Mark and D-Mark was the DM price for Mark bank notes that had been illegally "exported" from the GDR to West Ger. many. However, this rate, which is shown in figure 1 , is not representative of the underlying fundamental relative price of Marks in terms of DMs for several reasons. First, it was subject to speculative influences which made it very volatile ${ }^{16}$ Second, it reflected demands by East Germans for certain goods (e.g., consumer electronics and coffee that were highly taxed in the GDR; table 2 shows that the Mark prices of these products in the GDR were about five times higher than their D-Mark prices in West Ger. many. Third, the arbitrage (flow) of subsidized East German products to the West has remained relatively weak due to transaction costs and trade restrictions.

Another possible candidate for the "true exchange rate" to use for conversion purposes might have been the so-called "Devisenrentabilitaet" (foreign exchange profitability) of GDR exports in terms of their DM equivalent. This rate is calculated by dividing the Mark value of the aggregate GDR exports by their DM revenue when they are sold to West Germany. In 1989, this ratio, which was used by the GDR government for all internal conversion calculations, was 4.4 Marks per DM. Again, however, this ratio does not indicate what the market exchange rate would be. First, the domestic prices of many GDR export products were artificially high due to taxes imposed by the GDR; consequently, the numerator of the ratio is heavily influenced by tax policy, not economic values. Second, export decisions were made by the GDR government primarily to obtain foreign exchange to finance its imports. It is evident that this non-market allocation process, which is typical of centrally planned economies, ${ }^{17}$ is not representative of market-based trade; among other consequences, it can lead to exports with very low profitability. ${ }^{18}$

A thind alternative is the official 1M:1DM exchange rate set in the past by the East German Government. ${ }^{19}$ Like all such official exchange rates established in socialist countries, this was an arbitrary rate used primarily as an accounting unit which embodies no useful economic information relevant to determining the rate to use for Gmu conversion purposes. ${ }^{20}$ All foreign exchange transactions were conducted at flexible (implicit) exchange rates which were the ratios of the internal Mark price to the world market DM price of each product. ${ }^{21}$
15See Frenkel and Goldstein (1986), Williamson and Miller (1987).

16It varied from 16: (November 17, 1989) to $3: 1$ atter the definitive conversion rate for non-GDR residents had become public.

17See Wolf (1985b, pp. 215).

rasee Cornelsen and Kirner (1990).

tountil 1989 , this rate was also used for the "forced exchange" ("Zwangsumtausch") of DM 25 for West Germans who wanted to visit East Germany. From the beginning of 1990 , West German travelers could exchange D. Marks at a $1: 3$ rate against Marks.
20The same criticism applies to the exchange rates agreed to by the East and West German governments in December 1989 when they established a fund to exchange bank notes for travel; Each East German ciłizen was entit!. ed to purchase up to 100 DN at a 1DM:1M rate and an additional 50 DM at a $1 D M: 5 M$ rate.

21 See Wolf (1985b). 
Figure 1

Exchange Rate for Mark Banknotes (M per DM)

Daily values for bid and ask prices

October 2, 1989-April 4, 1990

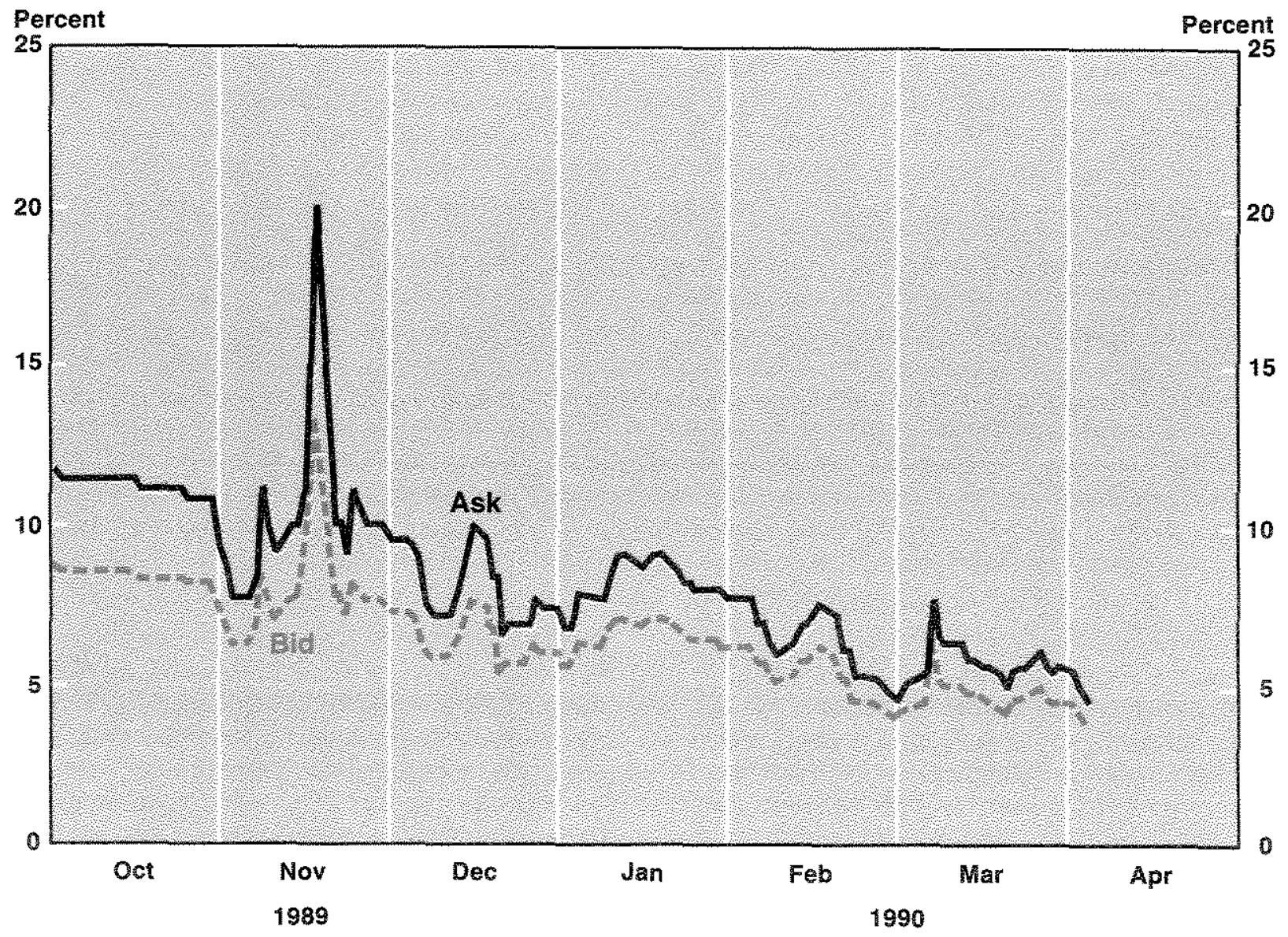

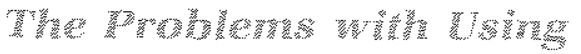

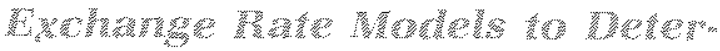

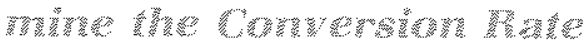

The lack of reliable market exchange rates to use in setting the Gmu conversion rate might tempt one to consider using one or more traditonal exchange rate models to calculate an appropriate "equilibrium exchange rate." Several approaches to exchange rate determination appear in the international economics literature; among the alternative approaches are purchasing power parity (PPP), structural exchange rate models and the so-called "underlying balance approach". ${ }^{22}$

A detailed discussion of these approaches is beyond the scope of this paper. However, they have limited usefulness in the Gmu context because they were developed primarily to explain exchange rate fundamentals in economies with open financial markets. All variants of PPP, 
Table 2

Consumer Prices of Selected Goods and Services in the GDR and the Federal Republic of Germany (1985)

\begin{tabular}{|c|c|c|c|}
\hline Good/Service & $\begin{array}{l}\text { Price in } \\
\text { (M) CDA }\end{array}$ & $\begin{array}{l}\text { Price in } \\
\text { (DU) FRG }\end{array}$ & $\begin{array}{l}\text { Mrice as a percent } \\
\text { of the DM price }\end{array}$ \\
\hline Potatoes $(5 \mathrm{~kg})$ & M4.05 & DM5.32 & 76 \\
\hline Tomatoes (1 kg) & 4.40 & 210 & 210 \\
\hline Pye Bread $(1.5 \mathrm{~kg})$ & 0.93 & 4.54 & 21 \\
\hline Beef $(1 \mathrm{~kg}) \quad$ & 9.80 & 1945 & 50 \\
\hline Chocolate (100 g) & 3.85 & 0.89 & 433 \\
\hline Cotfee $(250 \mathrm{~g})$ & 2500 & 5.25 & 476 \\
\hline Jeans (men's) & 135,00 & 59.90 & 225 \\
\hline Brown coal $(50 \mathrm{~kg})$ & 3.51 & 19.40 & 18 \\
\hline FadlolCassette Fecorder & 16000 & 19995 & 580 \\
\hline Color TV & $5,650.00$ & 1,19900 & 471 \\
\hline Bent ( 1 bedroom) & 3500 & 300,00 & 19 \\
\hline Electricity $(75 \mathrm{kwh})$ & 750 & 29,30 & 26 \\
\hline Halreut (mant) & 190 & $11 \times 25$ & 17 \\
\hline Rallway Joket $(50 \mathrm{~km})$ & 400 & 9,20 & 43 \\
\hline
\end{tabular}

SOURCE Materialien zum Bericht zur Lage der Nation, 1987 pp $513,516,732,735$

for example, rely on the "law of one price" holding in integrated and competitive markets. ${ }^{23}$ The relative version of PPP, developed by Gustav Cassel to determine equilibrium exchange rates after World War $\mathrm{I}^{24}$ relates the required exchange rate adjustment between the currencies of two countries with different inflation rates. However, this procedure requires the existence of an unbiased base period in the past, a condition which clearly is not met in the GDR setting.

The absolute version of PPP avoids the base period problem by defining an equilibrium exchange rate as the ratio of the price of a standard market basket of goods in one currency to the price of the same basket in another currency. Thus, the consumption basket of an average GDR household could provide one basis for absolute Ppp calculations of an appropriate Mark/D-Mark exchange rate. In 1985, for example, the goods and services which made up this basket (excluding rents) had a DM equivalent value which was 10 percent higher than their
Mark price. ${ }^{25}$ If we assume that the GDR price level has remained unchanged while the market basket's DM equivalent value has risen at the inflation rate in West Germany since 1985, the price differential would be about 15 percent in 1989. Thus, an absolute PPP exchange rate based on consumer prices (for a given market basket of goods and services) would be 1.15DM:1M or a 1DM:0.9M conversion rate. However, due to high subsidies and the existence of a "monetary overhang" (explained later in the paper), indicative of an excess demand for goods in the GDR, the economic relevance of such calculations is severely limited. ${ }^{26}$

Because most structural exchange rate models (e.g., those based either on the monetary approach with fixed or flexible prices or on the portfolio balance approach) require either shortterm or long-term PPP to hold, they are beset with the same conceptual drawbacks as the simple Ppp calculations already discussed. In addition, they presume that people are able to engage in unlimited arbitrage between financial
23See Cassel (1918, 0. 413): "As long as anything like tree movement of merchandise and a somewhat comprehensive trade between the two countries takes place, the acm tual rate of exchange cannot deviate very much from this purchasing power parivy."

24See Dombusch (1987) 25including rents the difference was 25 percent

zan atternative PPP measure, the "Dovisenrentabliteet" violds an equilibrium exchange rate of IDM:4.4M. However, the problems of this specific measure have already been discussed. 
markets in the respective countries; this condition did not exist in the GDR prior to the Gmu. ${ }^{27}$

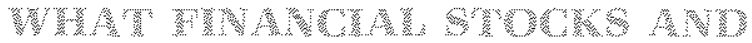

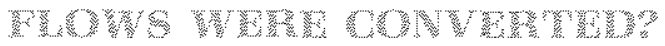

In order to clarify the issues associated with the Gmu, this section presents a brief discussion of the main items whose values were converted from Marks to DMs in the process of monetary unification. Throughout the paper, a distinction will be made between financial stocks and financial flows.

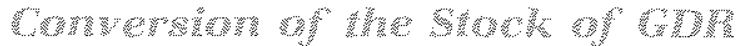 W

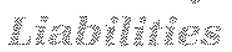

The stock of financial assets in the GDR is represented by the consolidated balance sheet of its banking system presented in table 3 . In contrast to how these accounts would be drawn up in the United States, the loans and liabilities of the central bank ("Staatsbank") must be added to the state-owned commercial banks on a consolidated basis. As is typical in most centrally planned economies, the GDR did not permit direct financial transactions between enterprises and households ("dichotomized money supply"). ${ }^{28}$ Therefore, this consolidated balance sheet presents a comprehensive picture of the stock of all financial assets and liabilities in East Germany.

The principal items on the asset side of the banking system were loans to state-owned enterprises, housing (chiefly state-owned), direct credits to the government, and claims on foreigners. Loans to households were negligible, making up less than 1 percent of all bank assets. In contrast, such loans represent about 23 percent of bank assets in the Federal Republic.

Savings of private households are the most important liability of the GDR's banking system. The consolidated balance sheet prior to the Gmu also shows a considerable amount of foreign liabilities. However, the bulk of these foreign liabilities (M 96 billion) was simply an accounting item ("Richtungskoeffizient") arising from the GDR's practice of valuing its foreign assets and liabilities af a 1DM:4.4M exchange rate rather than at its "official" 1DM:1M exchange rate. After Gmu, of course, the DM denominated foreign debt of the GDR will be valued at its face value. The revaluation of foreign assets and liabilities also reduced the amount of external claims (from $M 45$ billion to DM 36 billion) and the debt of the government (from M 61 billion to DM 12 billion).

After revaluation of foreign assets and liabilities and the overall 1DM:2M conversion of all domestic items, except for the limited 1DM:1M conversion of savings, the liabilities of the GDR banking system (DM 246 billion) exceeded its assets (DM 220 billion) by DM 26 billion. This difference was created by the asymmetric conversion of the left and the right side of the consolidated balance sheet produced by an effective 1DM:1.4M conversion rate of total savings. To equilibrate their balance sheets, East German banks were given interest-bearing government assets from an equalization fund established by the GDR for this purpose. Except for this fund, the post-Gmu balance sheet shows that the net bank debt of the actual GDR government sector is relatively small (DM 7 billion).

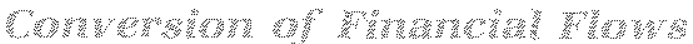

The 1DM:1M conversion rate for financial flows determined the D-Mark equivalent for Mark-denominated wage and rent contracts in existence prior to July 2,1990 . Although these contracts can (and undoubtedly, will) be renegotiated after this date, a legal transformation of existing contractual obligations from their previous Mark payments into DM payments ("rekurrenter Anschluss") was required. ${ }^{28}$ For all new contracts and those old contracts for which payments could be adjusted immediately or on short notice, the conversion rate was irrelevant. GDR pensions were treated somewhat differ-
2This also excludes the application of the "underlying balance approach to exchange iate assessment," which was developed by the Intemational Monetary Fund. According to Wilamson and Wither 1967,0 . 10\%, who have claborated this method, the "ftundamental equilibrim exchange "ate" is defined as the rate "which is expected to generate a current accoun suptus or defict equal to hine underlying captal fow over the cycle, given that the coun-
Wy is pursuing "intemal balance" as best as it can and not restricting trade for balance of payments reasons."

${ }^{25}$ See Woll (1985a).

aspoole (1990) emphasizes, on purely economic grounds, that "any attempt to conven prices of goods and services from OM (Ostmark to Dh through wentral direction can only cause great dithiculy." 


\section{Table 3}

\section{Consolidated Balance Sheet of the Banking System of the GDR as of May 31, 1990}

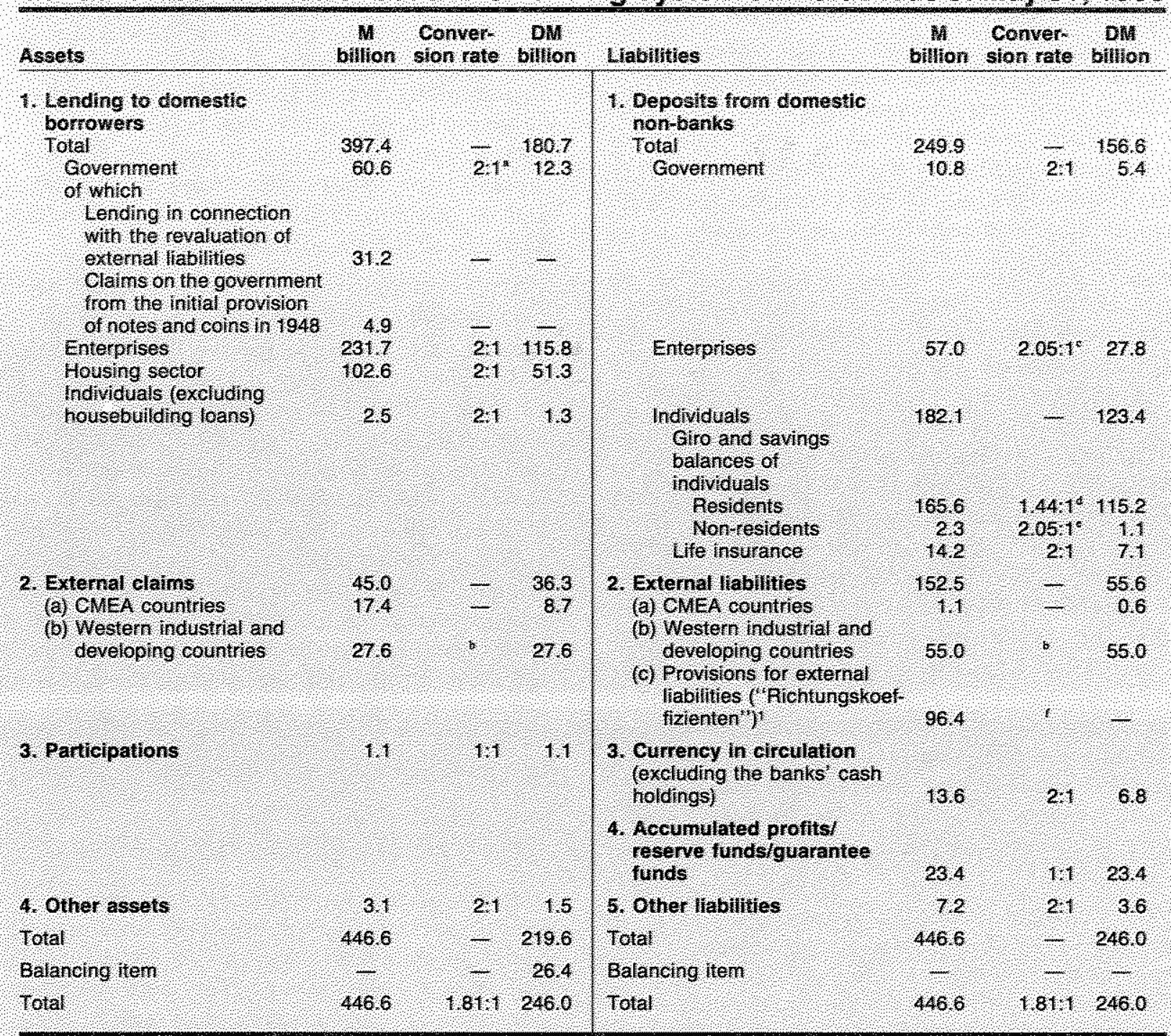

These are actually liabilites of the banking sector to the govemment, which night also be shown in liabilites len 1 in this table, they are showh n connection with the oxtenal labblities of the GDR because the ten nay also be regalded as a knd of Value acjusment for he external liabilites, which are onherwise put at too low a value in Gon Makk.

Conversion of a balance of M 245 bllion, which results after oftsetting the lending tom the revaluation of external liabilites (M 372 bilion) and claims arising fron the nitial provision of notes and coins in 1946 (M 4.8 billon) against provisions for extenal liablities ("Richtungskoffizienten') to the same anount.

External clains (assets lien 2 (b)) and external labilles (habitites lem $2(\mathrm{~b})$ ) are here stil valued at the accounting tates of the end of 1989 . The market rates of June 30,1990 are $\mathrm{b}$ be used for the final conversion. The amounits shown wil then presumably be sonewhat lower (labilties item $2(b)$ also includes foreign curency deposits from esestents)

conversion rate tor balances of non-tesidents arsing on and ater January 19903,1 otherwse 2

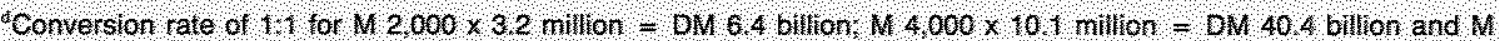

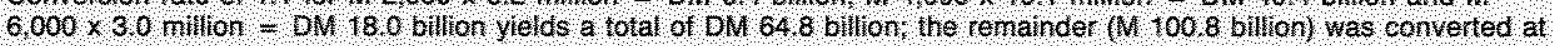
a tate of 2 .

Balances as at the end 01089 amounting o $\mathrm{M} 2$, biffon were converted at 2, , he renainder at 3.

Panty offsel egainst landing in connection with the revaluation of extemal fiabilites ( 332 bilion and claims arising from the initia provision of hotes and coins $\mathrm{h} 1948 \mathrm{M} / 9$ billon), the arithmetical remainder $(\mathrm{M} 60, \mathrm{billon})$ was used 10 reduse the balancing tem 
ently. As already mentioned, the social union adjusted the GDR pension system to make it consistent with West German standards; among other things, this meant that the DM value of GDR pensions was not less than their previous Mark value.

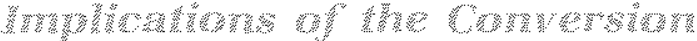

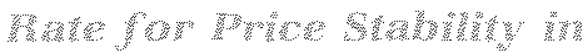

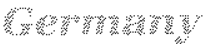

For West Germans, who traditionally have placed a very high social value on price stability, concern over the implications of the Gmu on the inflation rate played a predominant role in the choice of the conversion rate. The existence of an excess supply of money, which, by Walras' Law, reflects rationing on goods and labor markets, ${ }^{30}$ is a widely acknowledged occurrence for centrally planned economies, including the GDR ${ }^{31}$ Many observers expected that a flat 1M:1DM conversion of the East German money stock would produce a rise in the price level and, hence, a transitory increase in the measured rate of inflation for the integrated German currency area after the Gmu.

The expected impact of monetary unification on the German inflation rate can be determined as follows: First, estimate a hypothetical GDR money stock that would be compatible with stable DM prices in the GDR; second, compare this hypothetical money stock with the actual DM money stock of the GDR after conversion. If the actual money stock exceeds the hypothetical one, the conversion could produce a tem. porary increase in inflation in both Germanys; otherwise, the conversion does not have inflationary implications.

To accomplish the first step requires calculating the East German money demand after the Gmu. To do this, of course, one has to estimate the velocity of money and potential nominal production of the GDR economy. The following estimates are based on the assumption that both relative and absolute DM prices in the GDR as well as the GDR's velocity of money will be identical to their West German counterparts after unification. GDP potential production can be estimated either by using its GNP, which is about 13 percent of West Germany's GNP, or some measure of potential output determined by relative labor productivity estimates. This latter method ${ }^{32}$ uses the proportion of the East Germany population to West German population (about 26 percent) and the estimated average GDR labor productivity relative to that in West Germany (about 50 percent) to obtain a relative GDR potential production of about 13 percent, which is identical to the relative GNP differential noted above. Use of a lower estimate of the GDR productivity differential, for instance, the 30 percent estimate of the Kiel Institute for World Economics, reduces the GDR's potential production to only about 10 percent of that in the FRG.

This approach can be used to determine the "non-inflationary" conversion rates for different monetary aggregates; various estimates are shown in table 4. Applying the West German ratio between potential output to the stock of currency yields a conversion rate of about 1M:1DM for East German currency holdings. To calculate a non-inflationary M1 money measure for the GDR requires determining the "moneyness" of the various GDR deposit categories. If the "Spargiro" (M 69.0 billion) and deposits of enterprises are essentially demand deposits and the "Buchsparen" (M 90.7 billion) are essentially the same as traditional savings deposits included in M3, the pre-Gmu GDR M1 money stock was about one-third of that in West Germany. Thus, the non-inflationary conversion rate for the GDR's M1 money stock would lie in the $1 \mathrm{DM}: 2.4 \mathrm{M}$ to $1 \mathrm{DM}: 3.3 \mathrm{M}$ range. Using the $\mathrm{M} 3$ money stock, the non-inflationary conversion rate would lie within 1DM:1.5M and 1DM:2M. ${ }^{33}$

Comparing East and West German money stock measures is always problematical because there is a much wider spectrum of financial opportunities available to West German investors. Their savings in long-term time and savings deposits, bank savings bonds and other financial instruments issued by banks, which are called "monetary capital" and not included in M3, are larger than the M3 money stock. Adding these financial assets to the West German M3 money stock yields a liquidity stock measure (L).
30 See Commander and Coricelli (1990), p. 3.

31See Sokil and king (1989).

32tt which was suggested by the President of the Kiel Insinute for World Fonomics, Horst Siebert. 33in West Germany, the money stock M3 includes currency in circulation (exciuding banks' cash balances), sight deposits, time deposits with a maturify of less than fots years and savings deposits at statutory notice. 
Table 4

Conversion Rates on the Basis of a Non-Inflationary Money Stock for the GDR (1989)

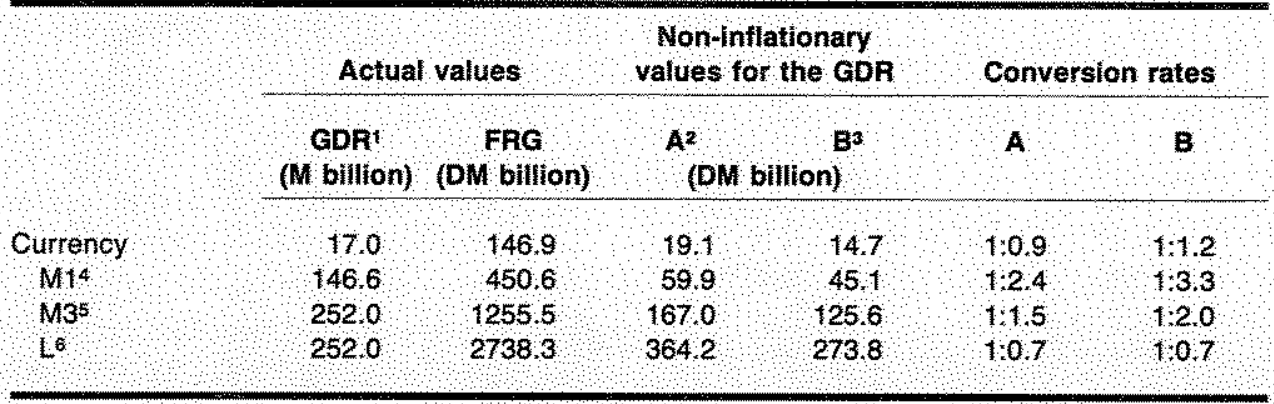

Values for the GDA include deposits of enterprises and households with the banking system.

2 Assuming that GDR potential output is 133 percent of FRG potental output

sAssuming that GDF potential output is 10 percent of FRG potential output

scurrency in circulation and domestic non banks sight deposits

sMT plus domestic non banks' lime deposits and funds borrowed for less than 4 years plus savings deposits at statutory notice

GM3 plus saving deposits at agreed notice, longterm time deposits, bank savings bonds and other financial instruments heid by private households and enterpilses with banks.

SOURCE Deutsche Bundesbank, Monalsberichte, Jahresbericht 1989 der Staalsbank der DDA

In contrast, savings deposits and currency are the only financial stores of value available in East Germany ${ }^{34}$ Thus, for East Germany, L and M3 are identical. Using the L measure, the noninflationary conversion rate would be about 1DM:1M. However, in order to make the converted East German L measure truly comparable to the West German $L$, about 50 percent of East German savings would have to be "frozen" for about four years.

As table 4 shows, an assessment of the inflationary impact associated with the Gmu depends on which monetary aggregate is regarded as the one linked most closely to inflation. Most econometric estimates for the Federal Republic show a very stable relationship between the money stock, M3, and inflation (and nominal GNP); this is the reason why the Bundesbank uses M3 as its main inflation indicator and as its central intermediate monetary policy target. ${ }^{35}$ Taking M3 as the benchmark money stock for non-inflationary purposes suggests that the conversion rate for the GDR money stock should lie in a range between $1 \mathrm{DM}: 1.5 \mathrm{M}$ to $1 \mathrm{DM}: 2 \mathrm{M}$. While the latter value was recommended by the Bundesbank, the political compromise reached between the two governments led to an average conversion rate of about $1 \mathrm{DM}: 1.7 \mathrm{M}$. While the estimated non-inflationary conversion rates shown in table 4 are subject to considerable uncertainty, the final conversion program chosen for the Gmu seems unlikely to produce any substantial inflationary impact on prices in the new DM currency area.

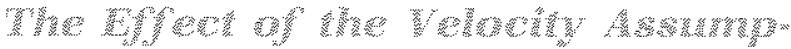

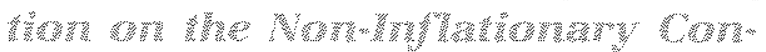

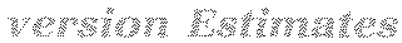

The non-inflationary conversion calculations described above assumed that the velocity of the appropriate money stock in the GDR is identical to that in the FRG. Some observers in the Federal Republic have argued that countries with higher per capita income levels have different monetary velocities from those in lessdeveloped countries. Figures 2 and 3 show the results of a cross-country analysis comparing
3hThis aspect was emphasized by he East Ceman Contral Bank "Staktsban") in en ofticlal statement of April 3 , 1990. 3s So Deusche bundesbank (1989a), Schlesinger and Jahnke (1987). 


\section{Figure 2}

\section{Velocity of M1 and GNP per Capita for OECD Countries}

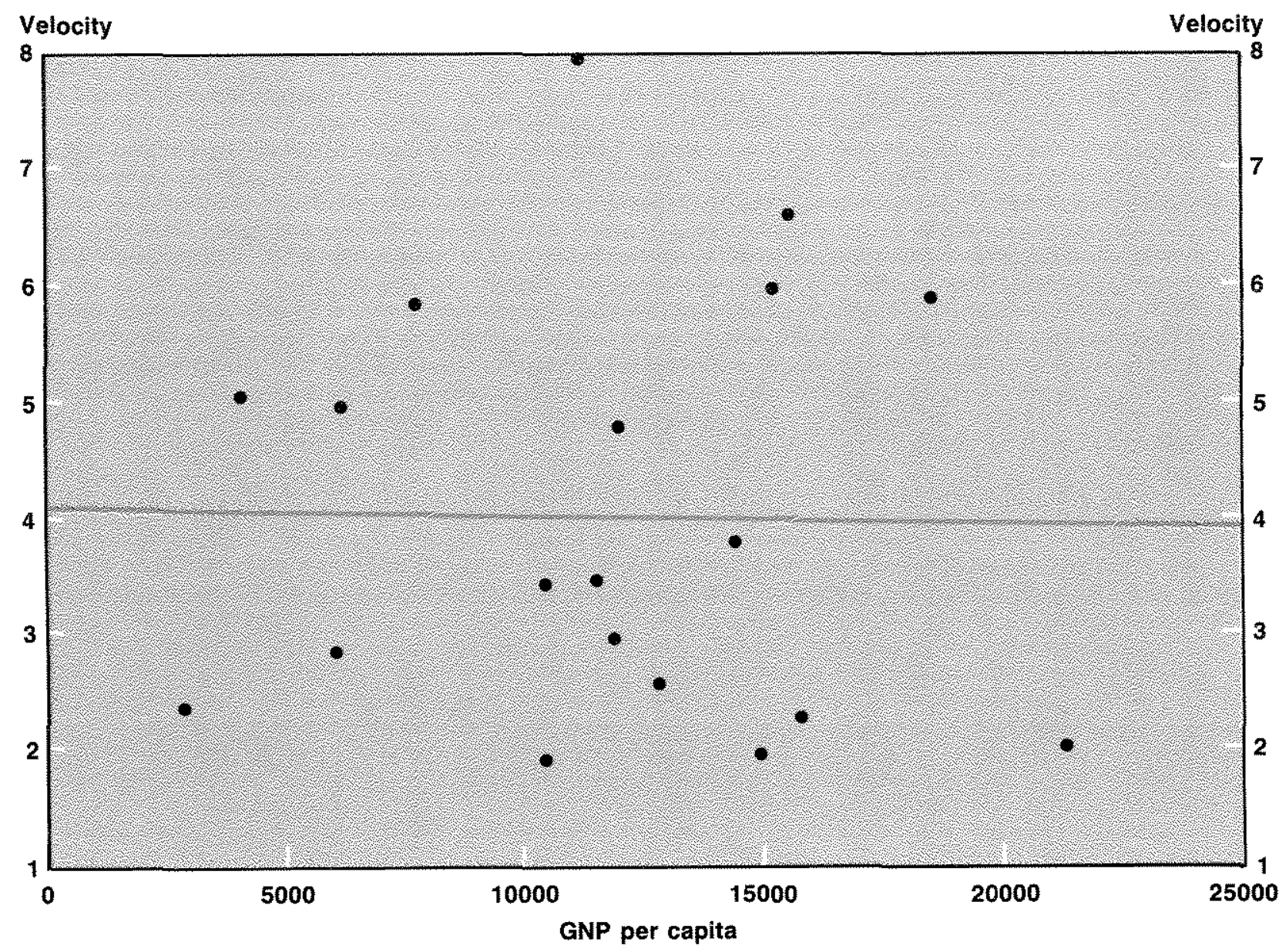

per capita nominal incomes and velocities for the M1 and M3 money stocks in OECD countries in 1987. The figures indicate that per capita income has no significant influence on the velocity of money. However, the marked intercountry differences in the velocity of money serves as yet another reminder that the noninflationary GDR money stock calculations are subject to considerable uncertainty.

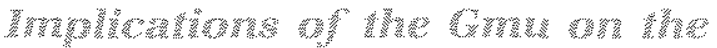

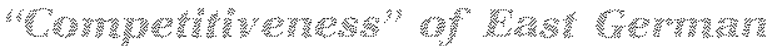 W}

The potential impacts of the Gmu on the unemployment rate in the GDR and its economic growth prospects were another im- portant determinant of the conversion rate. While West Germans were concerned about the possible fiscal costs of unemployment payments to East Germans, the East Germans, as noted earlier, were primarily interested in the prospects for employment and for raising their standard of living as quickly as possible. These prospects depend fundamentally on how competitive the GDR firms will be after the central planning process is dismantled and the economy of the GDR is opened up to world markets. While it is evident that the conversion of enterprise debt has a direct impact on the financial structure and capital costs of firms in East Germany, the implications of the conversion rate for wages in the GDR are more difficult to evaluate. 


\section{Figure 3}

\section{Velocity of M3 and GNP per Capita for OECD Countries}

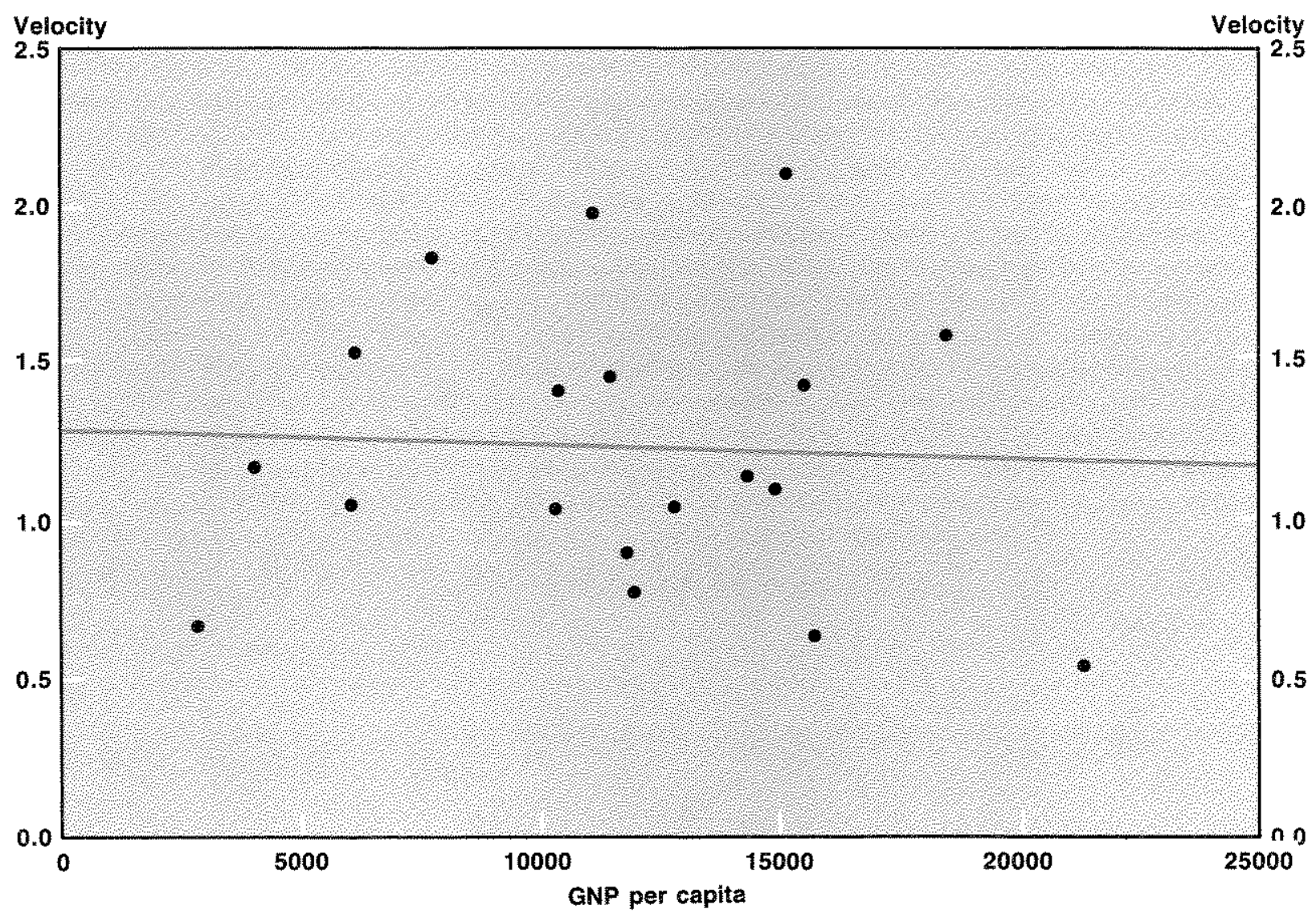

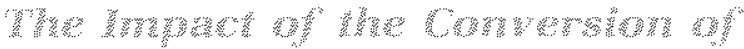

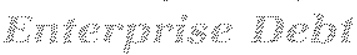

The 1DM:2M conversion rate for financial stocks determines the debt burden and interest payments of enterprises after the unification process. ${ }^{36}$ It has important consequences for the costs of capital and for the projected privatization of East German firms. The latter, an essential element of the process of economic transformation, requires that the firms to be privatized must have a positive net worth. For enterprises that will remain under state ownership, the ratio of their DM equity to their total
DM assets after conversion will play a key role in determining whether they can survive with a "hard budget constraint," i.e. without subsidies from the government.

Because there is no data on the debt-equity ratios of East German enterprises, it is difficult to assess the implications of the $1 \mathrm{DM}: 2 \mathrm{M}$ conversion rate on their financial situation and on their interest payments. To get a rough estimate of the sustainability of alternative debt burdens, however, the proportion of GDR potential output to FRG potential output can be used; as already mentioned, estimates vary between 10

36 Again, the conversion rates which were put forward in the debate varied widely, ranging from a 100 percent debt reliet which was recommended by the five leading German 
and 13 percent. According to Bundesbank (1989) statistics, the net financial debt of West German enterprises texcluding housing and the financial sector) was DM 681.5 billion and the book value of their non-financial assets totaled DM 1096.5 billion in 1988. The FRG figures indicate that a 1DM:1M conversion for the debt of GDR enterprises would have produced a relatively large DM 175 billion net debt (see table 3), about 26 percent of the West German level. ${ }^{37}$ If East German firms' nonfinancial assets are worth about 10 to 13 percent $^{38}$ of that for West German firms, the right side of their balance sheets would have exceeded the left side (DM 110-140 billion) by huge amounts, even if West German firms' balance sheets contain extensive hidden reserves. Without further debt reduction, privatization of virtually all East German firms would have been impossible. According to West German bankruptcy law, which requires bankruptcy proceedings if a firm has negative net worth, most East German firms would have had to be declared bankrupt.

of course, an outright cancellation of all GDR enterprise debt would have avoided these problems. However, this "solution" was dismissed for two reasons: First, firms with permanent net debt levels are common in all industrialized countries; second, it would have led to a huge increase in the government debt as described later in this paper. The debt reduction ${ }^{39}$ achieved by the 1DM:2M conversion rate places the average ratio of equity to assets for GDR enterprises in a range between 20 and 37 percent, which should allow the privatization of at least some firms. By comparison, the average equity to asset ratio is about 20 percent in West Germany and 50 percent in the United States. ${ }^{40}$

Because the results are quite sensitive to the estimate of the value of real assets in the GDR, it is difficult to assess whether the interest burden of East German firms will be similar to the West Geman enterprise sector or whether it will be significantly higher. In addition, it is not yet clear whether East German firms will have to pay market-determined interest rates on their debt after monetary uniftcation.

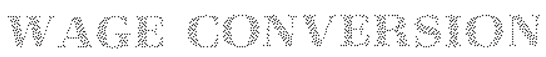

The second determinant of East German firms ${ }^{3}$ post-conversion competitiveness are the DM wages they will have to pay. While neither the GDR nor the FRG government should determine wages after the transition to a market economy, their treaty established a wage conversion rate to define the financial obligations of existing contracts for the time immediately after July 2, 1990. However, the actual conversion rate chosen has implications for wage levels and competitiveness only if nominal DM wages in the GDR after conversion are inflexible downward and if initial DM wages are set "too high" compared with labor productivity.

These considerations would have called for a conversion rate that reduced average wages below the level indicated by the GDR's average productivity. The advantage of this low starting level for wages is that it would have allowed workers and firms in East Germany to renegotiate their contracts more easily after Gmu. This would have enabled them to establish a wage structure more closely matching sectoral productivity differentials than the prior GDR wage structure, in which wages were relatively uniform regardless of productivity differences.

To evaluate the competitiveness of East Ger. man firms after a 1DM:1M wage conversion, their labor productivity relative to that in comparable West German firms must be compared with their relative DM wages. These comparisons would require information on the productivity of individual firms or, at least, individual sectors in the GDR after July $2,1990$. Unfortunately, such sectoral data are not avallable all moreover, estimates of labor productivity in the GDR after the transition to a market economy are very difficutt to determine ex ante. However, the experience following the West German curpency fefom in June 1948 shows that large productivy gains can be achieved rather quichy; these gains arise from better incentives associated with the market process and increased avalablity of inputs. In
37 A high debt burden is regarded as a typical concomitant of the central planning mechanism, which gives enterprises automatic bank credits indueing large hoardings of inventories or camouflaging cost overuns, waste and sales in the tolack market (Grosstikar 1989, 0 . 31).

3BOn the basis of a Cobp-Douglas production function and assuming an identica elasticity of oupul with respect to capha as in West Germany, Alexander and Gagnon (1990) estimete the level of ine Eas German cantal stock to be 10.4 percent of he Wost Beman capita shok.

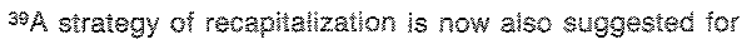
oher Easten Europan counies. See Hindis $(1900,0.44)$

4 See bank for Intmationa Sethemens (1989, $p .96$ ). 
the GDR, where such incentives are lacking, shortages of specific inputs are often reported to have led to significant decreases in output and productivity. ${ }^{4 \mathrm{I}}$

On the other hand, the far-reaching restructuring of production processes will not be possible without some temporary output disruptions.$^{42}$ If these positive and negative effects roughly cancel each other in the first few months after conversion, the GDR's productivity should reach about 50 percent of that in West Germany, which is consistent with past estimates made by the Deutsches Institut fuer Wirtschaftsforschung.

Before the conversion took place, the average monthly salary of a worker was $M 1250$ in the GDR and DM 3192 in West Germany. With the 1DM:1M conversion of the initial nominal wages, monthly wage costs (including employers' contributions to social security) for East German firms would be about 37 percent of West German wages. ${ }^{43}$ Thus, the average DM wage level in the GDR after the conversion is not so high relative to the average productivity differential between GDR and FRG workers that it would preclude future wage negotiations.

However, the initial wage differential cannot be held constant by the government after the Gmu. Therefore, the medium-term outlook for employment as well as for foreign and West German investment in the GDR will depend mainly on the rate of subsequent wage increases in the GDR. If these exceed the growth of productivity in the GDR, employment and investment in GDR firms will fall.

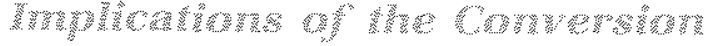

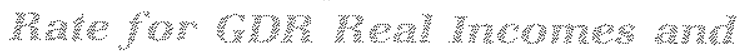

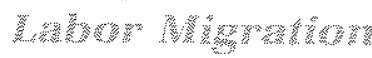

Because the unification process has been driven primarily by the desire of East Germans to improve their standard of living, the effects of monetary unification on the FRG-GDR real income differential were intensively discussed in both East and West Germany. However, since wages will be renegotiated after the Gmu, monetary unification will have only a short-term impact after July 2, 1990 .

An estimate of the change in East German real incomes resulting from the Gmu can be calculated by assuming that nominal wages in the GDR will remain constant after conversion and after the various subsidies are abolished. The basis for comparing pre- and post-Gmu real incomes in the GDR is the consumption basket of an average GDR household that was discussed earlier.

The abolition of trade restrictions and product-specific taxes and subsidies will produce price structures and a price level in East Germany similar to that in West Germany. Thus, the Gmu will cause a "one-shot" consumer price increase of about 15 percent for the unchanged GDR consumer goods basket. ${ }^{44}$ In addition, the increase in social security contributions, due to the introduction of the West German social security system into East Germany, will reduce the average net monthly income of an East German worker from M 1050 to DM 983 after unification. Together with the one-shot price adjustment in consumer goods, real incomes in the GDR will be reduced by about 21 percent. ${ }^{45}$

\footnotetext{
${ }^{41}$ According to a survey of the Institut der deutschen Wirtschat, about one third of all GDR employees had to suspend their work for wo of more hours per day because of shortages and defective machines.

aln the past, all decisions on investment, production and sales were made by the central planning bureaucrats; managers of firms were mainly responsible for technical operations.

43The 1DM:2M conversion rate proposed by the Deutsche Bundesbank differs less from the 1DM: $1 \mathrm{M}$ rate chosen than one might assume at first glance. In its calculations, the Bundesbank assumed that all subsides would be Femoved before conversion, requing an increase in Mark wages of about 25 to 30 percent to compensate for this eftect. If these new Mark wages were then converted at a $1 D M: 2 M$ rate, the effective conversion rate between initial East Germar Mark wages and DM wages atter the Gmu
}

would have been about $1 \mathrm{DM}: \mathrm{i} .2 \mathrm{M}$. Including the employer's contribution to social security, the initial labor costs in the GDR would have been about one third of the West German level if the 1DM:2M conversion rate had been used.

44This change from Mark prices to D-Mark prices has no effect on the overall German intlation rate which is measured on the basis of the DM equivalent of goods and services.

45These orders of magnitude show that conversion rates for GDR incomes considerably above IDM: $1 M$, for instance,

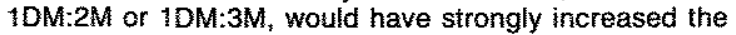
movement of workers from East to West Germany. Assuming constant consumption patterns, a $1 \mathrm{DM}: 2 \mathrm{M}$ (1DM:3M) rate woutd have reduced GDR real incomes by 57 percent (70 percent) compared to their pre-Gmu levels. 
The above calculations overstate somewhat the negative welfare implications of unification. Households will adjust to the price changes by purchasing more of the goods with relatively cheaper DM prices and less of those whose prices rose more because they had been heavily subsidized in the past. The prospective adjustment of the previous Mark price structure to the DM price structure is indicated in table 2 . As no detailed data on consumption patterns of East Germans are available, the quantitative relevance of this substitution effect is difficult to evaluate. ${ }^{46}$ The same comment applies to the positive welfare effects attributed to prospective quality improvements in available consumer goods; after the Gmu, East Germans will be able to buy West German products which, on average, are of better quality than their East German counterparts.

On balance, the real income of East Germans and the real income differential between East and West Germany will remain essentially unchanged immediately after the Gmu, with real net incomes in the East about 50 percent lower than in the West. This result reflects the fact that monetary unification by itself can only create a framework for real sector reform. Significant improvements in East German living standards will only be generated by better allocation of their resources and increased investment. Thus, the incentive for East German workers, especially skilled workers, to move to the Federal Republic of Germany remains at least as strong as it was before the Gmu. However, the prospect of a rapid and wideranging restructuring of the GDR economy has already improved the motivation of East Germans to remain in the GDR and contribute to its economic recovery. The number of GDR citizens moving to the FRG, which reached a monthly peak of 133,000 in November 1989 , fell to only 19,000 by May 1990 .

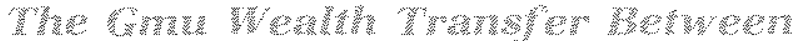

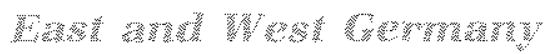

The Gmu will result in a wealth transfer from West Germany to East Germany, 47 The mechanisms and the quantitative effects of this wealth transfer, however, remain uncertain.
To examine this issue, even if a definitive answer is not forthcoming, it is useful to start with an example of a hypothetical currency unification between two market economies, e.g., between France and West Germany. Suppose that the DM is to be replaced by the Franc and that the current market exchange rate $(1 \mathrm{DM}=3 \mathrm{FF})$ will be used to convert all DM financial and real stocks and flows in their Franc equivalent. In this case, there is no transfer of real wealth; simply multiplying all $D$ Mark prices by three does not reallocate wealth within Germany nor between France and the Federal Republic. ${ }^{48}$ Redistribution of wealth between creditors and debtors in both countries could oecur only if that currency unification leads to unexpected changes in inflation and if some debtors or creditors had been expecting a parity adjustment. In this case, the net transfer between the two countries would then be determined by creditor/debtor relations between France and Germany and by the direction of the change in expectations.

In the Gmu case, there is no wealth transfer between GDR residents and West Germans due to unexpected exchange rate variations because there were virtually no financial linkages between individuals or enterprises in both countries prior to the Gmu. The asymmetric conversion of assets and liabilities, however, transfers GDR debt to the FRG (see shaded insert). Before the Gmu, the aggregate wealth of the East German economy consisted of its aggregate real assets and its aggregate net foreign claims (debts); domestic financial claims and liabilities simply cancel out in the aggregation process. Because monetary unification has no implications for the GDR's foreign claims and liabilities, it can increase the wealth of the GDR only if its domestic financial assets, which are mainly savings, are converted at a higher rate than its. domestic liabilities.

In a closed economy, even this asymmetric conversion would have no aggregate effect on the economy's wealth; the gap between assets and liabilities in the consolidated banking system would have to be filled by government
46An analysis of the Deutsches Institut fuer Wirtschaftsforschung comes to the result that private households can compensate the price effect by reducing their consumption of foods by 10 percent.

\footnotetext{
47See, for instance, Poole (1990).

$46 \mathrm{f}$ is assumed that a procedure for an equitable distribution of seignorage can be devised.
} 


\section{Mechanics of the Wealth Transfer Effected by Gmu}

The total wealth $\left(w_{\text {i }}\right)$ of each economic agent in the GDR is the sum of its real wealth (RW) plus is net monetary wealth $\left(\mathrm{NM}_{3}\right)$ :

(1) $\mathrm{w}_{\mathrm{i}}=\mathrm{RW}_{i}+\mathrm{NM}_{i}$

Net monetary wealth is the sum of claims on other GDR residents $\left(C_{i}^{\mathrm{OBR}}\right)$ and on foreigners (C) minus liabilities against GDR residents $\left(L_{1}{ }^{\infty R}\right)$ and foreigners $(L$, :

(2) $\mathrm{NM}_{1}=\mathrm{C}_{i}^{\cos }+\mathrm{C}_{i}^{\mathrm{F}}-\mathrm{L}_{i}-\mathrm{L}_{i}^{\mathrm{F}}$

Substituting (2) in (1) yields:

(3) $\mathrm{W}=\mathrm{nW}+\left(\mathrm{C}^{\mathrm{COR}}-\mathrm{l}_{\mathrm{i}}^{\mathrm{GOR}}\right)+\left(\mathrm{C}^{\mathrm{F}}-\mathrm{L}_{\mathrm{i}}\right)$

Total wealth of the GDR is the sum of individual total wealkh.

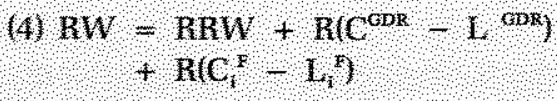

bonds. ${ }^{49}$ In the case of Gmu, the gap is closed by bonds which are issued by equalization funds established by East Germany. While these bonds are formally a debt of the East German government, they can actually be regarded as a financial obligation of West Germany, This conclusion is based on the wide-ranging financial support that West Germany agreed to provide to the East German public sector and the prospect of rapid political unification. The wealth transfer directly produced by Gmu is thus identical to the amount of bonds needed to equalize the consolidated balance sheet of the East Ger. man banking system after the Gmu. ${ }^{\text {so }}$

A second deteminant of the wealth transfer between East and West Germany is the distribution of the GDR's real wealh after conversion.
Canceling all intra-GDR financial claims and liabilities $\left(\mathrm{RC}_{5}^{\mathrm{BBH}}=\mathrm{RL}_{i}^{\mathrm{CoR}}\right)$ yields total wealth before Gmu:

(4a) $\mathrm{RW}=\mathrm{RRW}+\mathrm{R}\left(\mathrm{C}^{F}-\mathrm{L}\right)$

The asymmetric conversion of intra-GDR financial liabilities and claims $\left(\mathrm{RC}_{1}^{\mathrm{CDR}}>\mathrm{RL}_{\mathrm{i}} \mathrm{GD}\right)$ requires the creation of an equalization item (E) which leads to:

(5) $\mathrm{nC}_{\mathrm{OPR}}=\mathrm{nL}_{\mathrm{gm}}, \mathrm{E}$

If this equalization item is regarded as a financial liability of West Germany, (5) can be substituted in (4),

(6) $\mathrm{RW}=\mathrm{RRW}+\mathrm{R}\left(\mathrm{C}^{\mathrm{E}}-\mathrm{L}\right)+\mathrm{E}$.

Comparing $4 a$ and 6 shows that the wealth transfer, which is directly associated with Gmu, depends on the amount of this equalization item.

At the moment, most GDR firms are owned by the state. To the extent that these assets are transferred to a common German government, the net wealth transfer arising from the money stock conversion will be reduced. The same result would occur if these firms are sold at market prices and the proceeds are then used to repay part of the GDR government debt. This latter option is presently being discussed in the Federal Republic.

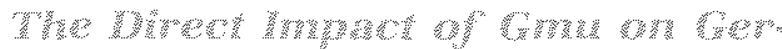 mrat}

The consolidated balance sheet of the GDR's banking system in table 3 shows that the 1DM:2M conversion of the GDR enterprise see-

downward, which would require urimployment bonents from Wos Gemany so East Gemany.
49This was the case in the West Gemen currency reform of 1948 .

skgmu would have indirect weath effects if it contributes io non-competive wages and if these wages are inflexible 
tor's net debt and the limited 1DM-1M conversion of savings (including currency) implies a DM 26 billion ( 5.3 percent) increase in the German central government debt. The impact of this asymmetric conversion would have been even higher if it were not for the "Richtungskoeffizient" discussed previously.

Using an assumed 8 percent interest, this additional debt will increase the German government's interest payments by DM 2.1 billion, about 0.7 percent of its total expenditure. A uniform 1DM:1M conversion of enterprise debt, savings and currency would have produced a DM 76 billion increase in government debt. If this debt were borne mainly by West German tax payers, this would have been identical to a wealth transfer of DM 1230 from each West German-in the form of an interest-bearing and non-repayable IOU-and would have provided each East German with an additional DM 4560 . This example illustrates why the 1DM:1M conversion rate for savings was controversial in West Germany after it had become evident that a 1DM:1M rate for enterprise debt was impracticable.

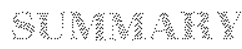

The set of conversion rates chosen for the Gmu has important implications for the debt burden of East Germany's enterprise sector, for the wealth transfer between both German states and for the level of West German government debt. The 1DM:2M conversion rate for enterprise debt may cause some financial difficulties for many GDR firms, but it will also lay the groundwork for the privatization of the more profitable enterprises. This result is a necessary precondition for the GDR's transition to a market economy. The ceilings for the 1DM:1M conversion of savings limit the wealth transfer from West Germany to East Germany to a relatively small amount. The same applies to the required increase in German government debt and its interest payments.

A (transitory) rise in the inflation rate of the common German currency area is unlikely after the Gmu. The post-conversion money stock in the GDR seems to be roughly compatible with the GDR money demand at the new DM prices.

The medium- and long-term impacts of monetary unification on the competitiveness of GDR firms, on unemployment and relative living standards in East Germany, and on the wealth transfer from the West Germans to East Germans has been widely overestimated. The ultimate outcome of unification will be determined by the productivity of East German firms, the real income necessary to encourage East German workers to remain in the GDR and the actual wage and income levels that will be achieved in East Germany.

Monetary unification has only have a short-term impact on the initial wages and incomes in the GDR. Because the conversion rates are compatible with the more pessimistic estimates of the productivity differential between East and West Germany, they do not appear to have produced the problem of too-high initial GDR wage levels and possible downward-stickiness of wages in the face of some initial unemployment pressures. Whether the prospects provided by the economic and social community of the two states and the farreaching financial assistance offered to East Germany by the West German government will suffice to keep skilled workers in the GDR remains open to question.

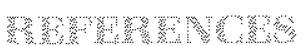

Alexander, Lewis S., and Joseph E. Gagnon. "The Globas Economic Implications of German Unification," International Finance Discussion Papers, No. 379 (Board of Governors of the Federal Reserve System, Aprił 1990).

Bank for International Settlements. 59th Annual Report (Basle, Switzerland, 1989).

Cassel, Gustav. "Abnormal Deviations in International Exchanges," Economic Journal (December 1918), pp. 413-15.

Collier, Irwin L. "The Estimation of Gross Domestic Product and its Growth Rate for the German Democratic Republic;" World Bank Staff Working Papers, No. 773, Washington, D.C., 1985.

Commander, Simon, and Fabrizio Coricelli. "Levels, Rates and Sources of inflation in Socialist Economies: A Dynamic Framework," paper prepared for a seminar in Laxenburg, Austria, March 6-8, 1990.

Committee for the Study of Economic and Monetary Union. "Report on Economic and Monetary Union in the European Community," Luxembourg, 1989.

Comelsen, Doris, and Wolfgang Kirner. "Zum Produktivitaetsvergleich Bundesrepublik-DDR," Deutsches Institut fuer Wirschaftorschung-Wochenbericht, April 5, 1990, pp. 172.74.

Daviddi, Renzo, and Efisio Espa. "The Economics of Rouble Converibility: New Scenarios tor the Soviet Monetary Economy," Banca Nazionale del Lavoro Quarterly Review (December 1989), pp. 441-65.

Deutsche Bundesbank. "The Monetary Union with the German Democratic Republic,' Monthly Report of the Deutsche Bundesbank (July 1990).

"The Deutsche Bundesbank. its Monetary Policy Instruments and Function;" Deutsche Bundesbank Special Series No. 7 (Frankturt, 1989a). 
"Enterprises' Profitability and Financing in 1988" Monthly Report of the Deutsche Bundesbank, (November 1989b).

Dornbusch, Rudiger. "Purchasing Power Parity" in Jorn Eatwell, Murray Milgate, and Peter Newman, eds., The New Palgrave: A Dictionary of Economics (London, 1987), pp. $1075-88$.

Frenkel, Jacob, and Morris Goldstein. "A Guide to Target Zones," IMF Staff Papers, Vol. 33 (December 1986), pp 633-73.

Gerstenberger, Wolfgang. "Das zukuenttige Produktionspotential der DDR-ein Versuch zur Reduzierung der Unsicherheiten," ifo-schnelldienst (July 1990), pp. 13-22.

Grossman, Gregory. "Monetary and Financial Aspects of Gorbachev's Retorm," in Christine Kessides et al, eds., Financial Retorm in Socialist Economies (Washingion, D.C.: World Bank, 1989), pp. 28-46.

Hinds, Manuel. "Issues in the introduction of Market Forces in Eastern European Countries," paper presented at an Economic Institute of the World Bank Conference in Warsew, Poland, March 12-13, 1990.

Institut der deutschen Wirtschaft. "Sozialverträgliche Ausgestaltung der Deutsch-Deutschen Währungsunion," Feport for the State of Lower Saxony from March 12, 1990.

Institute of International Finance. "Building Free Market Economies in Central and Eastern Europe: Challenges and Realities" (Washington, D.C., 1990).

Poole, William. "The German Democratic Republic: Economic Goals, Constraints and Monetary Reform," Shadow
Open Market Committee: Policy Statements and Position Papers, March 18-19, 1990

"Reform der Wirtschattsordnung in der DDR und die Aufgaben der Bundesrepublik, Stellungnahme einer deutschdeutschen Arbeitsgruppe," Deutsches Institut fuer Wirtschaftorschung-Wochenbericht, February 8,1990 , pp. 657\%.

Roe, Alan, and Jayanta Roy. "Trade Reform and External Adjustment: The Experience of Hungary, Poland, Portugat, Turkey, and Yugoslavia;" Economic Development institute of The World Bank Seminar Report, No. 16, Washington, D.C., 1989.

Schlesinger, Helmut, and Wiltried Jahnke. "Geidmenge, Preise und Sozialprodukt," Jahrbuecher fuer $\mathrm{Na}$ tionaloekonomie und Statistik, Vol. 205, pp. 410-26.

Sokil, Catherine, and Timothy King. "Financial Betorm in Socialist Economies: Workshop Overview" in Christine Kessides et al., eds., Financial Reform in Socialist Economies (Washington, D.C.: World Bank, 1989).

Williamson, John, and Marcus H. Miller. "Targets and indicators; A Blueprint for the international Coordination of Economic Policy," Policy Analyses in international Economics, Number 22, September 1987.

Wolf, Thomas A. "Economic Stabilization in Planned Economies," IMF Staff Papers, Vol. 32 (March 1985a), pp. $78-129$.

"Exchange Rate System and Adjustment in Planned Economies;" IMF Staff Papers, Vol. 32 (June 1985b), pp. 211-47. 